\title{
PROJETO LEITURA 94
}

\section{Objetivos e estratégias bem definidos podem fazer o trabalho com a literatura, em sala de aula, tornar-se uma atividade mais agradável, ajudando o desenvolvimento do senso crítico do aluno}

O projeto nasceu de uma constatação: o nosso aluno não lê. Mesmo aquele que cumpre o dever de dar conta do livro, que mensalmente é obrigado a ler, na realidade não o faz. Ele apenas transforma símbolos gráficos em conceitos. Não chega àquilo que pensamos ser uma boa leitura: uma confrontação crítica com o texto e as idéias do autor, a compreensão das relações, da estrutura ou construção e a interpretação do contexto. O adolescente é um receptor importante para nós, mas, muitas vezes, ele sozinho não consegue efetuar todos os processos característi$\cos$ do ato de ler (decodificação, compreensão, relações) e fundamentais para o desenvolvimento do intelecto. Uma pergunta surge dessa constatação: por que não lê? Várias respostas são possíveis. Algumas sensíveis no dia-a-dia da sala de aula.

$\mathrm{O}$ aluno não percebe a importância da leitura. Ele não sabe porque precisa ler, não conhece os objetivos da leitura. O menino é pragmático. Ele acha que precisa fazer exercícios, decorar conceitos, fatos, datas e, principalmente, tirar notas suficientes para uma aprovação mais ou menos tranqüila.

O nosso aluno não gosta de ler. Resposta que nos leva a outra pergunta: por que não gosta? Não gosta porque está desmotivado e desinteressado, e o que leva o adolescente a ler, mais do que o reconhecimento da necessidade, são as motivações e interesses que correspondem à sua personalidade e desenvolvimento intelectual.

A percepção da necessidade de ler pode levar o adolescente à leitura por obrigação, nunca por prazer. E a leitura por prazer é a nossa busca, talvez utópica. Mas... de que vive o educador? Portanto, cabe a nós percebermos motivações e interesses

\section{A AUTORA}

Marly Camargo B. Vidal

Professora de Língua Portuguesa para sétimas e oitavas séries da Escola Pacaembu.

\section{Sandra Martins da Rola}

Bibliotecária na Escola Pacaembu e professora de Fontes de Informação I na Faculdade de Biblioteconomia e Documentação da Fundação Escola de Sociologia e Política - FESP. dominantes no nosso leitor para atingirmos nosso objetivo - de modo prazeroso para o aluno, e por que não, para nós - instrumentalizar o aluno para que se torne um leitor autônomo.

Leitor, porque "nossa cultura está escrita, mesmo na TV e nos computadores. Nada foi feito até agora que 
substitua a palavra escrita como fonte de acesso ao conhecimento acumulado pela humanidade durante séculos"1.

Autônomo, porque a sociedade futura tem sido descrita, de forma antecipada, como a sociedade do aprendizado. O progresso técnico e científico se processa com uma tal rapidez que o indivíduo terá de ser capaz de uma auto-educação permanente para não ser atropelado.

\section{MOTIVAÇÃO E INTERESSE}

Por motivação entendemos impulsos e intenções que orientam o comportamento. Atitudes e experiências emocionais determinam os interesses que não são apenas preferências, mas possibilidades de escolher uma coisa em detrimento de outra.

As motivações são, basicamente, o prazer, a alegria de pôr em prática a habilidade intelectual da leitura, treinar a fantasia, a vontade, a simpatia, mas também a capacidade de identificar, relacionar e transferir. Os interesses correm paralelos ao modo de vida do adolescente, suas experiências. Apreciam fatos e personagens familiares que possam ser relacionados com sua realidade, aventuras, inclusive as espaciais, histórias de terror, o sobrenatural e o humor picante.

Se o professor conhece motivações e interesses deveria ser fácil escolher o livro agradável. Entretanto, sabemos que isso não é a verdade que vivenciamos no espaço de leitura extraclasse. O que mais se ouve é "que saco de livro".

\section{O PROJETO} do livro.

Objetivo: estimular a leitura, permitindo ao aluno a escolha individual

Estratégias: os alunos escolherão o livro de seu interesse, partindo de textos selecionados pela professora e bibliotecária. Receberão instruções e orientações para leitura e fichamento, bem como notações bibliográficas. Lerão o livro e terão sempre à disposição para qualquer dúvida de leitura a professora e/ou a bibliotecária.

Público-alvo: as sétimas séries da Escola Pacaembu.

Avaliação: a) seminário em grupos de, no máximo, quatro alunos;

b) ficha bibliográfica e resumo do enredo entregues, imediatamente, após a apresentação do seminário;

c) avaliação em duas frentes: grupo e individual;

d) no quarto bimestre o aluno fará uma prova individual e será mantido o item $b$.

Critérios: capacidade de organização do grupo, apresentação dos trabalhos, tanto seminário como escrito; síntese do enredo: percepção do essencial e acessório, relacionamento com a realidade vivida, levantamento e relacionamento dos problemas políticos, sociais, humanos tratados pelo texto.

1. KUPSTAS, Márcia. Sete faces: o conto revisitado. In: BANDEIRA, Pedro \& TUFANO, Douglas. Moderno guia de estudos. São Paulo: Moderna, 1994. 
Critério de nota: a nota não deverá, nunca, contribuir para a diminuição da média do aluno e sim ajudá-lo a melhorar seu rendimento.

\section{APLICAÇÃO DO PROJETO}

O projeto foi levado a efeito nos terceiro e quarto bimestres de 94 , nas três turmas de sétima série: A (22 alunos), B (22) e C (19), num total de 63. Os alunos foram à biblioteca da escola e escolheram os livros que mais os interessaram dentre os selecionados. Os alunos foram orientados pela bibliotecária a lerem as informações das orelhas e as introdutórias, se houvesse. Quando solicitadas, professora e bibliotecária prestaram esclarecimentos, principalmente quanto ao tema, mas nunca colocando juízo de valor. A bibliotecária orientou as notações bibliográficas. Tiveram trinta dias para ler e mais dez para o preparo do seminário e fichamento individual. Houve cinco alunos que fizeram o trabalho sozinhos porque escolheram livro único, e um aluno não leu, não fez. Utilizaram-se de quatro aulas durante uma semana para apresentação e tiveram o tempo que desejaram. $\mathrm{O}$ mínimo foi de 15 minutos e o máximo de 27 . Ao final de cada apresentação a professora fechou com comentários, procurando não diminuir ou desvalorizar os trabalhos.

A quinta aula da semana foi utilizada para comentários em conjunto classe/professora, questionamentos, perguntas, enfim, um momento livre em torno dos textos. No quarto bimestre o mesmo esquema foi seguido e, após trinta dias para leitura, os alunos se submeteram a uma avaliação individual, por escrito, que obedeceu aos critérios já relatados.

\section{A SELEÇÃO DOS LIVROS}

Baseou-se a seleção nos interesses apontados como próprios do adolescente: temas familiares, situações conhecidas, aparentadas com a realidade; aventuras, humor, mistério e terror. No terceiro bimestre os livros foram de contos e no quarto, "romances".

Terceiro Bimestre

NOME DO LIVRO

Da coleção A palavra é

1. A palavra é futebol

2. A palavra é mistério

3. A palavra é humor

4. A palavra é mulher

5. A palavra é amor

6. A palavra é cidade

7. A palavra é festa

8. Entre parentes

9. O assassinato do conto policial

10. Agenda inventada

11. O sorvete e outras histórias

12. Para gostar de ler vol. $\mathbf{1 3}$

13. Quem conta um conto

\section{ESCOLHAS}

9 alunos

6 alunos

4 alunos

1 aluna

0

0

0

8 alunos

7 alunos

8 alunos

1 aluno

15 alunos

3 alunos 
O livro O sorvete e outras histórias não foi lido pelo único que o escolheu; três alunos não leram A palavra é humor, e um não leu Para gostar de ler, portanto, cinco no total.

Quarto Bimestre

NOME DO LIVRO ${ }^{3}$

1. A maldição da fábrica

ESCOLHAS

2. O último mamífero do Martinelli

6 alunos

3. O tio que flutuava

4. O enigma do pássaro de pedra

2 alunos

3 alunos

5. Revolução em mim

4 alunos

6. Crescer é perigoso

2 alunos

7. Unidos pelo vexame

1 aluno

8. Amor de verão

11 alunos

9. Vínculos

6 alunos

3 alunos

10. Um velho velhaco e seu neto bundão

11. A espada do general

1 aluno

7 alunos

12. Agitação à beira-mar

4 alunos

13. Quem manda em mim sou eu

10 alunos

14. Casé, o jacaré que anda em pé

15. Computador sentimental

16. Em algum lugar no céu

Alunos que não leram: três da sétima $\mathrm{A}$, nem sequer escolheram.

\section{O ALUNO AVALIA O PROJETO}

Os alunos avaliaram suas leituras respondendo a um questionário que abordava o projeto propriamente dito: oportunidade de escolha, títulos à disposição, processo de avaliação; e os livros lidos: assunto, personagens (quais os mais apreciados e por quê); o último item solicitava ao aluno sugestões.

2. AGUIAR, Luiz Antônio. Agenda inventada. São Paulo: Atual, 1993.

LEITE, Márcia. Entre parentes. São Paulo: Atual, 1994. Ver a coleção: A palavra é... São Paulo: Scipione, 1988. Ver a coleção: Para gostar de ier. Histórias divertidas. São Paulo: Ática, 1993. v.3. Ver a coleção: Quem conta um conto. São Paulo: Atual, 1993. 6v.

RANGEL, Paulo. O assassinato do conto policial. 3.ed. São Paulo: FTD, 1991.

3. ABRAMOVICH, Fanny. Quem manda em mim sou eu. São Paulo: Ática, 1989.

ARAÚJO, Leusa. Agitação à beira-mar. São Paulo: Atual, 1993.

CAZARRÉ, Lourenço. A espada do general. 8.ed. São Paulo: Atual, 1993.

Um velho velhaco e seu neto bundão. São Paulo: Atual, 1992,

GÓES, Lúcia P. Vínculos. 5.ed. São Paulo: Atual, 1987.

GOMES, Álvaro C. Amor de verão. 2.ed. São Paulo: Moderna, 1992.

JAPIASSU, Moacir. Unidos pelo vexame. São Paulo: Atual, 1990.

KUPSTAS, Márcia. Crescer é perigoso. São Paulo: Moderna, 1986.

Revolução em mim. 4.ed. São Paulo: Moderna, 1991.

LIMA, José Américo. A maldição da fábrica. 7.ed. São Paulo: Atual, 1992.

NOVAES, Carlos Eduardo. Casé, o jacaré que anda em pé. São Paulo: Ática, 1993.

REY, Marcos. O último mamífero do Martinelli. São Paulo: Ática, 1993.

RICARDO FILHO. Computador sentimental. São Paulo: Atual, 1992.

SCLIAR, Moacyr. O tio que flutuava. São Paulo: Ática, 1988.

YASBECK, Ivan. Em algum lugar do céu. São Paulo: Scipione, 1993. O enigma do pássaro de pedra. 3.ed. São Paulo: Scipione, 1993. 
Todos os alunos responderam, até mesmo os que não leram, assumindo responsabilidade pela não leitura. Claro que o questionário ficou incompleto. A oportunidade de escolha foi louvada por todos.

Um aluno queixou-se da recusa da professora em não decidir por ele entre dois que gostaria de ler, um aluno especifica o fato de se trabalhar texto ficcional em seminário e também a orientação sem interferência da professora. Quanto aos títulos, $40 \%$ gostariam de mais livros de terror, suspense e mistério (não percebem diferenças entre eles) à disposição. Três alunos afirmaram não gostar de trabalhar em seminário porque colegas que não lêem se aproveitam da situação.

Os demais apreciaram a possibilidade de discutir o texto ficcional em grupo e a maioria encontrou dificuldades na parte escrita. Em relação aos personagens, todos justificaram a apreciação pela proximidade com a realidade, mesmo os que leram terror e mistério.

O item sugestões mostra, claramente, que os alunos não estão em condições de sugerir algo novo. Só dois foram capazes de acrescentar algo ao que foi feito, mesmo assim sem grandes inovações: dramatizar o texto e fazer trabalho visual; prova em grupo, respondendo às perguntas feitas oralmente pela professora (não soube justificar o oral da pergunta). Essa mesma aluna sugere aplicação de uma avaliação mista: prova escrita e seminário.

\section{CONCLUSÕES}

O aluno lê com boa vontade quando escolhe. A tensão diminui bastante, o ambiente torna-se mais agradável. Os alunos que não leram são constantemente desinteressados, não fazem as tarefas, não participam das aulas. Comparando-se com o primeiro semestre - os textos foram impostos - o desinteresse diminuiu bastante. Nota-se que o quarto bimestre apresentou um quadro melhor no aproveitamento. Fica a dúvida se essa melhora se deve à continuidade do trabalho ou à mudança do texto "conto" para "romance" juvenil. Esses mesmos alunos, na oitava série, continuarão o trabalho no Projeto 95, aplicado também às sétimas séries. $\mathrm{O}$ conto será retomado visto que os alunos da oitava já o experienciaram e os da sétima já foram trabalhados pela professora da sexta.

Outros dados como preferência por sexo e por turmas estão sendo tabulados, bem como atitudes durante a escolha, as quais denotam um forte jogo de influências entre os alunos e a busca de um livro com poucas páginas.

Cremos que só o fato de a leitura "obrigatória" acontecer num ambiente menos tenso, mais descontraído, agradável já vale a pena e aponta para a possibilidade de alcançar o aluno pelo seu interesse, sem deixar de prover suas necessidades. 